\title{
Contrasting sediment and water chemistry indicates the extent of the hyporheic zone in a polluted river system
}

\author{
Dariusz Ciszewski, Urszula Aleksander-Kwaterczak \\ AGH University of Science and Technology, Faculty of Geology, Geophysics and Environmental Engineering; \\ al. A. Mickiewicza 30,30-059 Krakow, Poland; e-mail:ciszewski@geol.agh.edu.pl
}

(C) 2016 Authors. This is an open access publication, which can be used, distributed and reproduced in any medium according to the Creative Commons CC-BY 4.0 License requiring that the original work has been properly cited.

Received: 4 April 2016; accepted: 14 June 2016

\begin{abstract}
The concentrations of zinc and cadmium were determined in the sediment cores sampled from the floodplain and the channel in the middle reach of the Biała Przemsza River valley (southern Poland). The results were compared to the river water and groundwater chemistry in order to reveal the average extent of the hyporheic flow. The loss of river waters through the river bed due to the natural migration modified by the drainage of the lead-zinc ore mine caused the strong pollution of the river bed sediments with heavy metals to the depth of almost three meters below the water table in the river. Moreover, the similar groundwater and river water chemistry at that depth suggests that the vertical extent of the hyporheic zone, which exceeds a depth of several meters below the channel, can be affected by the drainage of river waters by the lead-zinc mine. The lateral extent of the hyporheic flow, indicated by changes in groundwater chemistry and elevated heavy metal concentrations in the sediments, was of the order of dozen of meters. The investigation documents the large impact of the secondary in situ enrichment of sediments with heavy metals in the hyporheic zone.
\end{abstract}

Keywords: water, sediment, pollution, floodplain, Biała Przemsza River

\section{INTRODUCTION}

Water bodies constitute a wide integrated hydrologic system and should not be treated separately in view of water environment management (Boulton et al. 1998, Hancock et al. 2005, Humphreys 2009). Moreover, analysis of aquatic ecosystems should be undertaken in terms of all spatial and temporal factors (Danielopol et al. 2004). Indeed, investigations over the last two decades have increased our awareness of the relation between hydrogeology and groundwater ecology (Mugnai et al. 2015) and the interface between the surface and groundwater where the dynamic exchange of water takes place, defined as the hyporheic zone, has become central for stream ecologists and managers (Boulton et al. 1998).
Typically, river water infiltrates streambeds and shallow alluvial aquifers and some of this infiltrated water returns to the river after a relatively short subsurface flow (Elliott \& Brooks 1997). Hyporheic flow is driven by pressure gradients along the channel bottom and changes with channel and valley morphology, the grain size of sediment and water discharge. The hyporheic zone constitutes a shelter for hyporheos - organisms which are unique for this specific ecotone and play a very important role as a physical, chemical and biological filter capable of transforming nutrients and pollutants (Bourg \& Bertin 1993). The intensity of these transformations is influenced at a number of scales by water movement, permeability, substrate particle size, resident biota, and the physiochemical features of the overlying stream and adjacent aquifers (Ward 2016). 
The extent of the hyporheic zone can change along the river valley. In sinuous rivers it forms along river banks (Cardenas 2009), and in the wide alluvial valleys of a long meandering river, almost all of the river water can circulate through the lateral part of this zone (Kiel \& Cardenas 2014). In the low gradient reach of a sandy alluvial river the hyporheic flow can extend over hundreds of meters across the valley. It can be markedly reduced in the straightened, incised reach of a channelized river (Aleksander-Kwaterczak \& Ciszewski 2016). The hyporheic zone can also switch between gaining and losing conditions following river discharge changes both in the adjacent floodplain as well as in the channel over small depths of the channel bar and in the pool and riffle scale (Wroblicky et al. 1998). Most transformations of hyporheic flow chemistry take place in the subsurface of the channel bottom, therefore almost $80 \%$ of the investigations of the hyporheic zone concern the river bed up to one meter thick (Ward 2016). Higher depths or their parts extending beyond river banks are generally poorly recognized.

The chemistry of overbank sediments is usually considered to reflect the primary sediment pollution at the time of their deposition (Ciszewski 2003). The variability of heavy metal concentrations in the vertical sedimentary sequences is not considered to be significantly influenced by groundwater chemistry although such a phenomenon can be particularly well evidenced for rivers contaminated with metals from metal-ore mines where heavy metals associated with the very fine mineral particles can be permanent tracers for the extent of the hyporheic flow (Aleksander-Kwaterczak \& Ciszewski 2016). In the present study, zinc and cadmium concentrations were determined in sediment samples collected from both the floodplain and from the channel to the depth of up to several meters below the groundwater level. The results were compared to groundwater chemistry in order to reveal the average extent of the hyporheic flow in the selected reach of the Biała Przemsza River valley (southern Poland).

\section{STUDY AREA}

The Biała Przemsza River in its upper and middle reaches drains the western part of the Cracow Upland which is dominated by Jurassic and Triassic carboniferous rocks. These rocks form relatively narrow cuestas, $300-400 \mathrm{~m}$ a.s.l. high, separated by wider basins situated at $250-300 \mathrm{~m}$ a.s.l., which are filled with fluvioglacial deposits. The valley of the Biała Przemsza River is particularly narrow and relatively steep when it crosses cuesta sections and is up to $1 \mathrm{~km}$ wide in lower gradient sections filled with fluvioglacial deposits up to $50 \mathrm{~m}$ thick (Ciszewski 1998). We investigated the middle reach of the Biała Przemsza, in the $4 \mathrm{~km}$ long ravine formed in the Middle Triassic Cuesta and which is upstream of Sławków. In this cuesta section, the valley is about $50 \mathrm{~m}$ deep with steep and mostly forested slopes, whereas the width of the alluvial valley floor varies in the range of 100-150 m (Fig. 1).

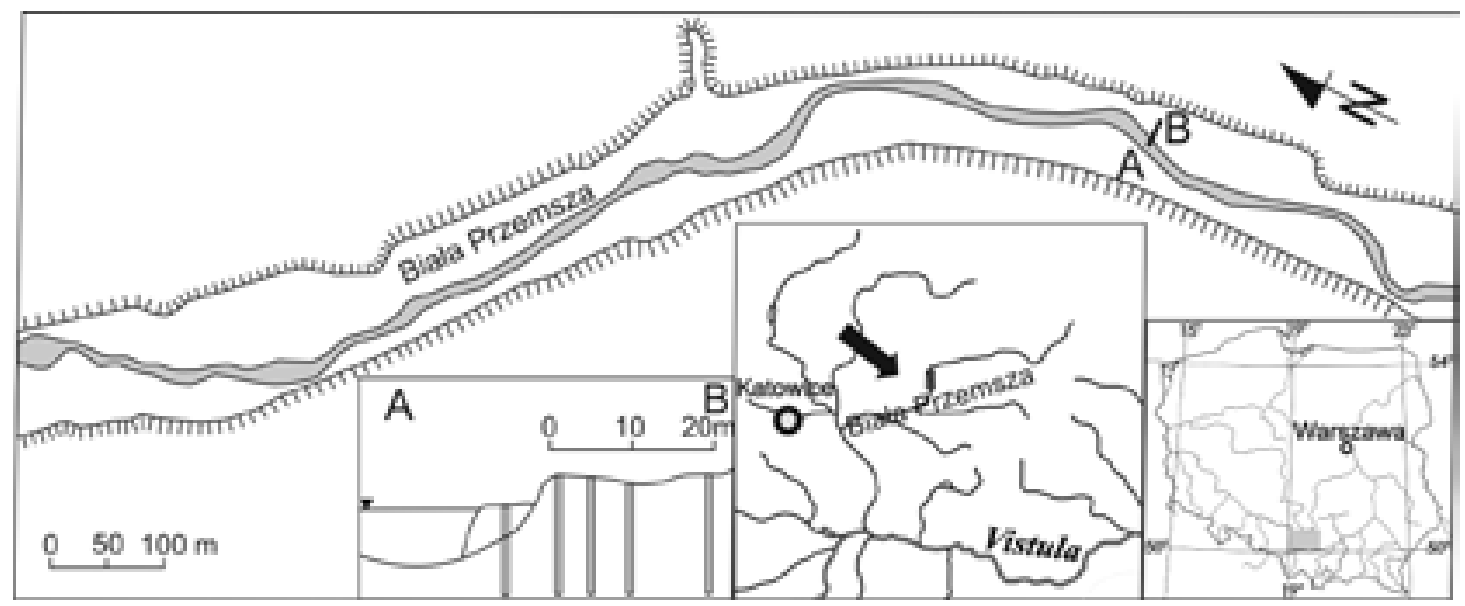

Fig. 1. Location of the investigation site and sampled profiles in cross-section AB in the middle reach of the Biała Przemsza River (the black triangle indicates the water table level in the river) 
The valley floor is terraced and remnants of the 3-4 m terrace stabilize the channel position for at least 100 years, as it is documented by topographical maps. Also an old mill as well as an associated weir and bank reinforcements located in Okradzionów, in the middle part of the cuesta section, contributed to the long-lasting channel stabilization. In this reach, the average discharge of the Biała Przemsza River equals $4 \mathrm{~m}^{3} / \mathrm{s}$, and about half of it originates from one of the largest lead and zinc mines in Europe - the "Bolesław" Mining and Metallurgic Plants (ZGH).

\section{METHODS}

In the Biała Przemsza River valley, about $1.5 \mathrm{~km}$ downstream of Okradzionów, five boreholes were drilled with a hand-held auger at points located in a cross-section perpendicular to the river channel. At each point one piezometer was installed (Fig. 1) and the sediment core collected. In the investigated cross-section the river channel is about $20 \mathrm{~m}$ wide and there is a side channel bar about a dozen meters long. The floodplain is about $1.0-1.5 \mathrm{~m}$ high over the average water table level and the left river bank has a width of about $50 \mathrm{~m}$ and it merges gently with forested valley slopes. The first borehole (SI) was drilled on the channel bar to the depth of $2.7 \mathrm{~m}$ below the water table level in the river which was close to an average. The borehole SII, which was located $1 \mathrm{~m}$ higher, in the channel bank, was also $2.7 \mathrm{~m}$ deep. The boreholes SIII and SIV drilled on the floodplain were deeper and reached $3.5 \mathrm{~m}$ and $3.7 \mathrm{~m}$, respectively. The borehole SV was situated in a small depression in the distance about $25 \mathrm{~m}$ from the channel edge and it was $3.1 \mathrm{~m}$ long. Sediment cores obtained from each borehole were divided into $10-30 \mathrm{~cm}$ long sections depending on changes in the sediment lithology.

The silty-clay grain size fraction of sediments $(<0.063 \mathrm{~mm})$ was obtained by wet-sieving and was analysed for zinc and cadmium content. The amount of $0.5 \mathrm{~g}$ of fine fraction was dissolved in $10 \mathrm{~cm}^{3}$ of $65 \% \mathrm{HNO}_{3}$ and $2 \mathrm{~cm}^{3}$ of $30 \% \mathrm{H}_{2} \mathrm{O}_{2}$ using a microwave digestion technique. The concentration of metals was determined by a flame atomic absorption spectrometer (F-AAS). Analyses were performed according to the standard certified analytical quality control procedure. Reagent blanks and certified reference materials were used to control the analytical accuracy. Results from the F-AAS method were confirmed with ICP-MS measurements, which attested to the very good analytical quality for both analytes.

Groundwater samples from piezometers as well as river water samples were collected four times every two months in the autumn-winter period when moderate flows prevailed. Groundwater samples were obtained using a low-rate submersible pump attached to a polyethylene hose. Conductivity values were established before water filtering whereas concentrations of $\mathrm{Cl}^{-}, \mathrm{SO}_{4}^{2-}, \mathrm{CO}_{3}^{2-}, \mathrm{Mg}^{2+}$ and $\mathrm{Na}^{+}$ were determined using Ion Chromatography (DIONEX 1000) in samples filtered within 48 hours through $0.45 \mu \mathrm{m}$ filters. The standard reference material (Canadian waters Hamilton-20) was employed to determine the accuracy of anion analyses.

\section{RESULTS}

Zinc concentration in sediments varies markedly between the investigated cores. The highest concentrations of this element were recorded in profiles sampled from the channel bottom and the bank side (SI and SII, Fig. 2). The content of this element changes from the maximum value at the bed surface to the minimum value at a depth of $2.7 \mathrm{~m}$. Concentration decreases in both cores four times from about $4 \%$ to about $1 \%$, but in the core SII at the river bank the metal content decreases more rapidly. The zinc concentration in sediments from the floodplain (SIII, SIV and SV cores) contrasts with that observed in cores sampled from the channel. Average concentration in cores located closer to the river (SIII and SIV) varies from $1,500 \mathrm{mg} / \mathrm{kg}$ to $3,000 \mathrm{mg} / \mathrm{kg}$ whereas most $\mathrm{Zn}$ content values throughout the core furthest from the channel (SV) fall below $1,000 \mathrm{mg} / \mathrm{kg}$. There are no regular changes in concentration variability for these cores. In the core SIII the highest concentration is observed in the top of the sediment while in the core SIV - at the depth of $3.5 \mathrm{~m}$.

Distribution of cadmium concentrations in investigated cores follows that observed for zinc. There are maximum concentrations of this metal in sediments cores taken from the channel, in which content of $\mathrm{Cd}$ at the surface layer is four times higher than that observed in the deepest part of sediment. 

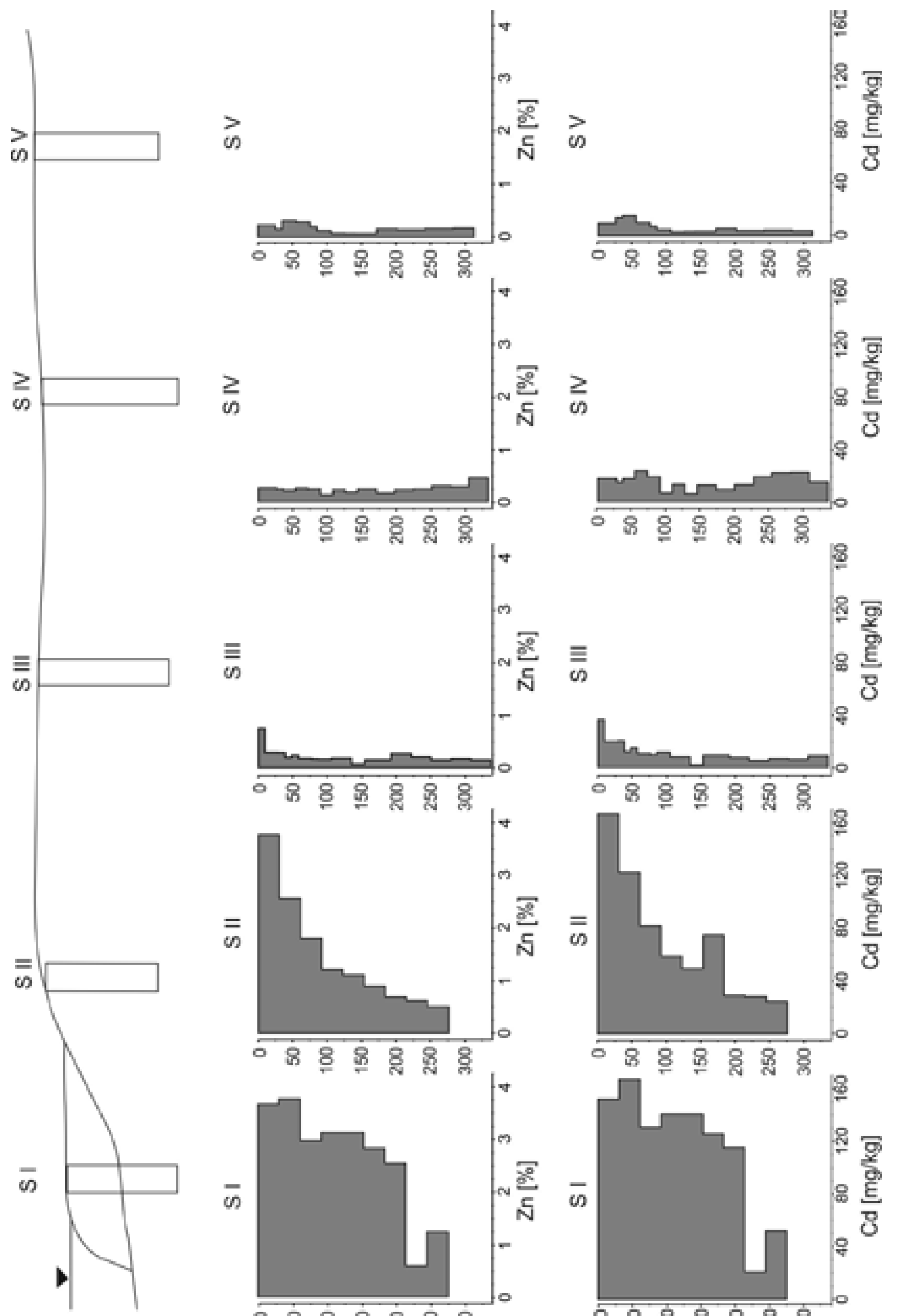

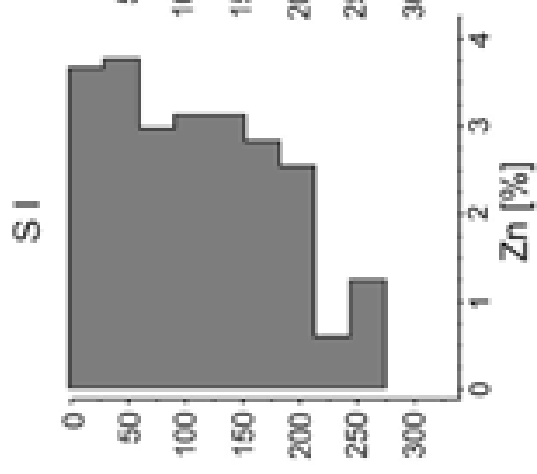

[w] undep

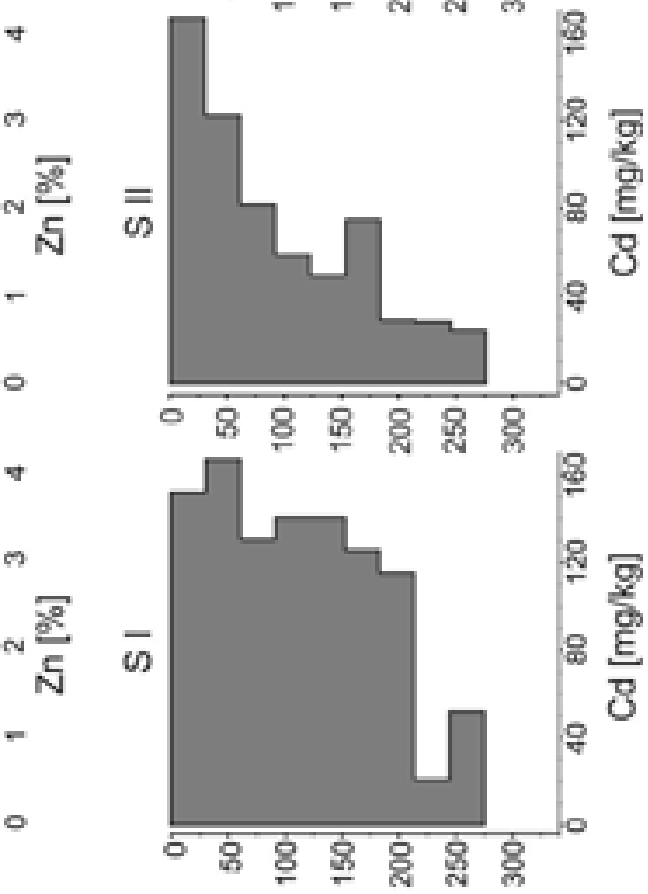

[w] updep 

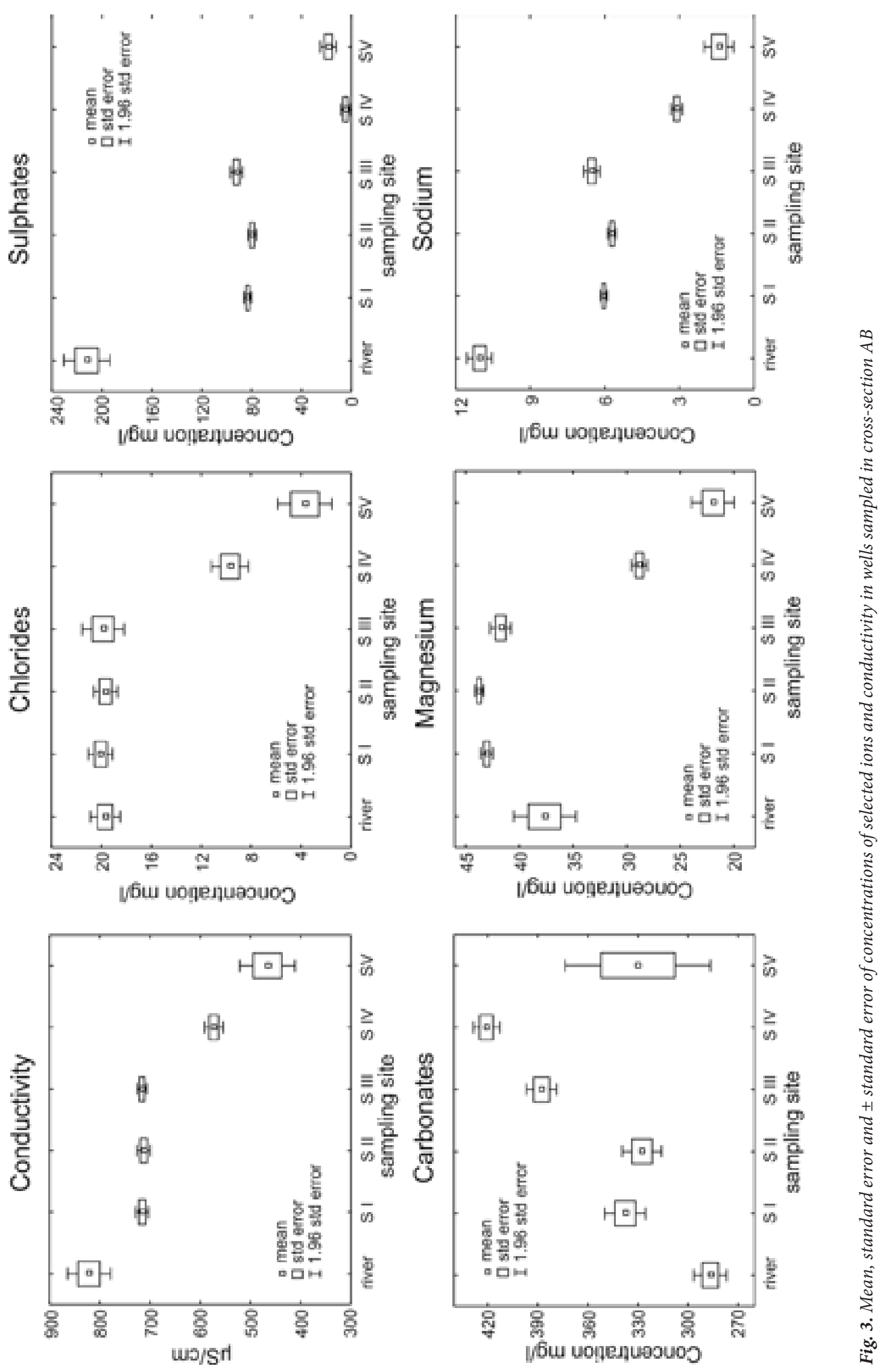
Cadmium concentrations in floodplain cores vary from $5 \mathrm{mg} / \mathrm{kg}$ to $20 \mathrm{mg} / \mathrm{kg}$. The highest concentration is measured in the top $10 \mathrm{~cm}$ of the SIII core and reaches $35 \mathrm{mg} / \mathrm{kg}$. A concentration below $5 \mathrm{mg} / \mathrm{kg}$ occurs in the deeper section of the core SV while in the top layer of that depth profile the cadmium content rises to over $10 \mathrm{mg} / \mathrm{kg}$.

In the case of water samples, the concentration of all analytes varies in narrow ranges (Fig. 3). The highest value of conductivity, exceeding $800 \mu \mathrm{S} / \mathrm{cm}$, is observed in samples from river water. This parameter's value is lower than $100 \mu \mathrm{S} / \mathrm{cm}$ in groundwater samples collected from the channel (SI and SII) and at the floodplain edge (SIII). Conductivity decreases markedly beyond the SIII core. In the SV core, located about $25 \mathrm{~m}$ from the channel, it reaches a value which is half of that measured in the river water. The distribution pattern of the chloride content resembles that of conductivity. Concentration of chlorides in the river water, under the channel and at the floodplain edge is very similar whereas, in the more distant points from the floodplain chloride content is even 5 times lower.

The water of the Biała Przemsza River is heavily polluted with sulphates. About 2.5 times lower concentrations (about $80 \mathrm{mg} / \mathrm{L}$ ) were observed in groundwater from the SI-SIII locations. Sulphate content drops to a dozen miligrams per liter in the SV point and is even lower in the SIV location. In contrary to other ion concentrations, the content of carbonates is the lowest in river water and in groundwater it increases with the distance from the channel from values below $300 \mathrm{mg} / \mathrm{L}$ to the maximum in SIV, about $420 \mathrm{mg} / \mathrm{L}$ on average. It then drops by about $100 \mathrm{mg} / \mathrm{L}$ in the SV location. The content of magnesium in the surface water is also lower than in groundwaters close to the channel but differences fall within the range of $10-20 \%$, reaching maximum values of $45 \mathrm{mg} / \mathrm{L}$. They drop by two times further from the channel and are the lowest in the SV location. Sodium is an element present in the largest amount in the river water. Its content decreases by almost half in groundwater close to the channel and further to SV location.

\section{DISCUSSION}

There is a broad range of available techniques that can be used to determine interactions between groundwater and surface water. Apart from numerical modelling, methods used for the quantification of the flow rate can be grouped in direct measurements of water flux, heat tracer methods, methods based on Darcy's Law and mass balance approaches (Kalbus et al. 2006). For contaminated watercourses, where differences between the river water and the composition of groundwater can be expected, migration of the pollution plume can be estimated from the variability of contaminant concentration in water samples from monitoring wells. Information about the distribution of contaminants depends on the density of the monitoring grid and can be used for small-scale studies of the hyporheic zone (Kumar et al. 2009). In the present study, five wells representing different water chemistry were used. For piezometers installed in the bed (SI) and in the bank (SII) of the Biała Przemsza River channel, the groundwater chemistry is very similar to the composition of the river water. An analogous relationship was found in groundwater from the SIII well, situated on the floodplain in the distance of about 5 meters from the river bank. Of particular interest is that the same content of chlorides in groundwater from SI-SIII points and in the river water can indicate the hyporheic flow. It extends under the channel bed and along the river in an approximately 5 meter wide zone. The small variability in water chemistry can indicate that this width was constant at average flows which prevailed during the investigated period. The lower content of most ions (except for carbonates) at the site SIV, situated about $15 \mathrm{~m}$ from the channel, suggests the presence of a mixing zone of water originating both from the river and the valley slopes. Furthermore, the relatively low content of conservative chlorides in the water from this well suggests a predominance of less mineralized water from slopes over the river water. This proportion can probably change depending on water discharges and rainfall intensity. Considering the definition of the hyporheic flow, which says that proportions of the river water should be at least $2 \%$ (Woessner 2000), this part of the floodplain seems to be marginal for that zone. The distribution of carbonate content is the opposite of the other determined ions; their progressive increase from the channel to the SIV location could be inversely related to the rate of the hyporheic flow. The lowest flow rate, which could be expected at the margin of the hyporheic 
zone (SIV), probably favors the dissolution of the dolomite-rich alluvia.

Generally, the chemistry of groundwater located the longest distance from the channel (SV) represents values of all of the investigated parameters, in contrast with other sampling sites. This indicates that there, water originates rather from the valley slope than from the river. This well is situated at the foot of the valley slope, where dolomite gravels underlie sandy alluvial deposits. Rough gravel surfaces, precluding their long fluvial transport, prove the connection of this area with the slope. Furthermore, low groundwater conductivity and the content of the ions in the SV location is much more similar to spring water of this area than to contaminated river water (Ciszewski \& Bijata 2015).

Zinc and cadmium in the Biała Przemsza sediments originate from the lead and zinc mine at Bukowno. The operation of the mine since 1954 has resulted in the very high pollution of the entire middle and lower reach of this river. Concentrations of zinc and cadmium in the channel sediments in 1992 at Okradzionów reached $3-4 \%$ and $120-180 \mathrm{mg} / \mathrm{kg}$, respectively (Ciszewski 1998). A very similar content of these metals can also be observed in samples from surface parts of sediment cores from the SI and the SII locations. This indicates the persistency of the metal pollution in sediments and also favors its longterm preservation in the investigated cores. This high pollution of sediments reaches a depth of almost $3 \mathrm{~m}$ below the river bed and contrasts with the order of magnitude of the lower pollution of the floodplain. This situation can be explained by the infiltration of the river water into the river bed. Downward seepage pulls fine-grained particles into the bed until they clog pore spaces in the material found in the bottom of the watercourse (Chen et al. 2013). The bed sediments of the Biała Przemsza are almost totally composed of sand, and therefore the water-borne sediments infiltrating the bed must be very fine with the finest particles of several micrometers in diameter bearing the highest amounts of metals (Horowitz 1991). A study by Karwan \& Saiers (2012) suggests that clay-sized particles and colloids can migrate within the pore space of sediment by stream water filtration in sand. It seems that these particles are responsible for the very high pollution of mainly the subsurface sediment layer whereas deeper and less polluted layers are enriched due to processes of direct absorption and precipitation from solution. However, it is difficult to evaluate the actual role of a metal transfer between a solution and a solid phase; dissolved metals can play a potentially minor role in this process because their concentrations are usually 3-4 orders of magnitude lower in water than in sediment. The long morphological stability of the river channel in the studied narrow ravine section of the cuesta, evidenced from maps, and much higher zinc and cadmium contents at similar depths under the channel than under the floodplain precludes primary pollution of the hyporheic zone by vertical sediment accretion and the raising of the river bed by over $2.5 \mathrm{~m}$ during about 60 years of the mine operation.

Despite the fact that hyporheic flow is rarely studied in the deeper sediment strata, the obtained results indicate that it may totally change sediment and water chemistry at a depth of at least 3 meters. The observed concentrations of metals in bottom sediments are by 1-2 orders of magnitude higher than the geochemical background. It implies that water that migrates from the river can influence much deeper levels and karstic aquifers below alluvial deposits. It can be a matter of discussion as to the extent to which the selected river reach is specific in this respect. On one hand, sandy alluvia and Triassic dolomites dominated by karst processes naturally favour losses of water from the channel and are characteristic for many reaches of the Biała Przemsza River but, on the other hand, part of the middle course of the river is affected by a depression cone of the lead-zinc mine in Bukowno. The mine has pumped waters since 1960s, and in 1970s-1980s the cone reached the river section located to the east of Okradzionów. It was estimated that in the several kilometer long reach, the river lost from about $0.5 \mathrm{~m}^{3} / \mathrm{s}$ of water at moderate river discharges to as much as $3.5 \mathrm{~m}^{3} / \mathrm{s}$ at extreme flood flows (Motyka \& Różkowski 2001). Metal mining in Bukowno and sand extraction could also be responsible for the loss of waters from the Sztoła River, which flows several kilometers in the south-east direction from the investigated reach. It was estimated that this river, due to mining operations in 1980s, switched from gaining to losing conditions (Czop \& Morman 2012). The Sztoła River is similar to the Biała 
Przemsza on that respect that it cuts fine-grained alluvia and transports waters from the ore mine containing suspended matter contaminated with heavy metals. In 1972, losses of even $50 \%$ of the water over a long reach of about $8 \mathrm{~km}$ were ascertained whereas in 2011 the river lost only about $20 \%$ of its discharge (Czop \& Morman 2012). It was suggested that the clogging is the main constraint for losses of water over the period of the last 40 years. However, the different water stages and the dimensions of the sand pit are also considered as the reason of decreased river discharge. Taking into account such mechanisms of the fine sediment migration in the coarser grained matrix, which results in raised metal concentrations in the fine fraction of bottom sediments, it seems that processes of clogging can hamper the draining of water in a similar manner for both rivers. Considering that the part of the investigated $\mathrm{Bi}$ ała Przemsza River reach is drained also by the lead-zinc mine it seems that the river could also have lost even $20 \%$ of the discharge (the recent estimations give a similar value of about dozen or so per cent for this reach; Czop M. pers. commun.). This suggests that the hyporheic zone in this river reach can be artificially extended to the depths which are not met in the naturally drained valleys; the width of this zone does not seem to have been markedly altered by anthropogenic activity.

\section{CONCLUSIONS}

In strongly polluted rivers, the extent of the hyporheic zone can be estimated based solely on the comparison of chemistry of the groundwater under the channel and in the floodplain. Heavy metal pollution of alluvial sediments in situ can give also an insight into the spatial extent and direction of the hyporheic flow.

On the investigated reach of the Biała Przemsza River, the net loss of water caused by natural migration into alluvial sandy and karstic aquifer has been enhanced by the drainage of water due to the lead-zinc ore mining. The lateral extent of the hyporheic flow is of the order of dozen or so meters wide whereas its vertical extent is far more than several meters below the channel. The loss of river waters through the river bed causes the strong pollution of sediments with heavy metals under the channel over a depth of almost 3 meters under the actual water table level in the river. High concentrations of metals at such a depth suggests that the content of metals exceeding the local geochemical background can be observed many more meters below the river bed. This is one of the first studies documenting such a large impact of the secondary processes on the in situ enrichment of sediments with heavy metals in the hyporheic zone.

The work was supported by National Science Centre project no. 2012/05/B/ST/10/00235 and by statutory research project no. 11.11.140.199 of the University of Science and Technology in Krakow.

\section{REFERENCES}

Aleksander-Kwaterczak U. \& Ciszewski D., 2016. Pollutant dispersal in groundwater and sediments of gaining and losing river reaches affected by metal mining. Environmental Earth Science, 75, 95, DOI:10.1007/ s12665-015-4859-8.

Boulton A.J., Findlay S., Marmonier P., Stanley E.H. \& Valet H.M., 1998. The functional significance of the hyporheic zone in streams and rivers. Annual Review of Ecological Systems, 29, 59-81.

Bourg A.C.M. \& Bertin C., 1993. Biogeochemical processes during the infiltration of river water into an alluvial aquifer. Environmental Science and Technology, 27, 661-666.

Cardenas M.B., 2009. Stream-aquifer interactions and hyporheic exchange in gaining and losing sinuous streams. Water Resources Research 45, W06429, DOI:10.1029/2008WR007651.

Ciszewski D., 1998. Channel processes as a factor controlling accumulation of heavy metals in river bottom sediments: consequences for pollution monitoring (Upper Silesia, Poland). Environmental Geology, 36, 45-54.

Ciszewski D., 2003. Heavy metals in vertical profiles of the middle Odra River overbank sediments: evidence for pollution changes. Water, Air, \& Soil Pollution, 143, 81-98.

Ciszewski D. \& Bijata P., 2015. Hyporheic zone hydrochemistry of the mine polluted river. Journal of Geoscience and Environment Protection, 3, 47-52.

Chen X., Dong W., Ou G., Wang Z. \& Liu C., 2013. Gaining and losing stream reaches have opposite hydraulic conductivity distribution patterns. Hydrology and Earth System Sciences, 17, 2569-2579.

Czop M. \& Morman J., 2012. Antropogeniczne przeobrażenia reżimu hydrogeologicznego rzeki Sztoły w południowej części rejonu olkuskiego. Przegląd Górniczy, 68 (7), 126-132.

Danielopol D.L., Gibert J., Griebler C., Gunatilaka A., Hahn H.J., Messana G., Notenboom J. \& Sket B., 2004. Incorporating ecological perspectives in European groundwater management policy. Environmental Conservation, 31, 3, 185-189. 
Elliott A.H. \& Brooks N.H., 1997. Transfer of nonsorbing solutes to a streambed with bed forms: Theory. Water Resources Research, 33, 1, 123-136.

Hancock P.J., Boulton A.J. \& Humphreys W.F., 2005. Aquifers and hyporheic zones: towards an ecological understanding of groundwater. Hydrogeology Journal, 13, 1, 98-111.

Horowitz A.J., 1991. A Primer on sediment-trace element chemistry. Lewis Publishers, Chelsea, Michigan, 1-136.

Humphreys W.F., 2009. Hydrogeology and groundwater ecology: does each inform the other? Hydrogeology Journal, 17, 1, 5-21.

Kalbus E., Reinstorf F. \& Schirmer M., 2006. Measuring methods for groundwater-surface water interactions: a review. Hydrology and Earth System Sciences, 10, 873-887.

Karwan D.L. \& Saiers J.E., 2012. Hyporheic exchange and streambed filtration of suspended particles. Water Resoures Research,48, W01519, DOI:10.1029/2011WR011173.

Kiel B.A. \& Cardenas M.B., 2014. Lateral hyporheic exchange throughout the Mississippi River network. $\mathrm{Na}$ ture Geoscience, 7, 413-417.

Kumar M., Ramanathan A. \& Keshari A.K., 2009. Understanding the extent of interactions between groundwater and surface water through major ion chemistry and multivariate statistical techniques. Hydrological Processes, 23 (2), 297-310.

Motyka J. \& Różkowski K., 2001. Wstepne wyniki badań ucieczek wody z Białej Przemszy na zawodnienie kopalni rud cynku i ołowiu „Pomorzany” (południowa Polska). [in:] XI. NHGK: hydrogeologie: multidisciplinární pojetí oboru: XI. národní hydrogeologický kongres: Ostrava, 19.- 21. Září 200: sborník. VSB-TU, Ostrava, 215-218.

Mugnai R., Messana G. \& Di Lorenzo T., 2015. The hyporheic zone and its functions: revision and research status in Neotropical regions, Brazilian Journal of Biology, 75, $3,524-534$.

Ward A.S., 2016. The evolution and state of interdisciplinary hyporheic research. Wiley Interdisciplinary Reviews - Water, 3, 83-103.

Woessner W.W., 2000, Stream and fluvial plain ground water interactions: rescaling hydrogeologic thought. Ground Water, 38, 423-429.

Wroblicky G.J., Campana M.E., Valett H.M. \& Dahm C.N., 1998. Seasonal variation in surface-subsurface water exchange and lateral hyporheic area of two stream-aquifer systems. Water Resources Research, 34, 317-328. 
